\title{
Review
}

\section{German Neurology and the 'Third Reich'}

\author{
Michael Martin ${ }^{a}$ Heiner Fangerau $^{a}$ Axel Karenberg $^{b}$ \\ ${ }^{a}$ Institute of the History, Philosophy and Ethics of Medicine, Heinrich-Heine-University Düsseldorf, Düsseldorf, and \\ ${ }^{\mathrm{b}}$ Institute for the History of Medicine and Medical Ethics, Medical Faculty, University of Cologne, Cologne, Germany
}

\section{Key Words}

Neurology/history · National Socialism/history · Eugenics/ history $\cdot$ Epilepsy/history $\cdot$ Euthanasia/history $\cdot$ Biomedical research/history · Neurosciences/ethics · Germany

\begin{abstract}
Background: This paper summarizes the current state of research into the role of German neurology during National Socialism (NS) on the basis of extensive secondary literature and key original sources. Summary: As early as 1933, many neurologists and neuroscientists who had been branded as 'non-Aryan' and/or politically persecuted had to leave Germany, were driven to suicide or killed in concentration camps. Two years later, the regulatory merger with the Psychiatrists' Association caused the cautious attempts of the institutionally hampered discipline for autonomy to end in complete failure. At the same time, the implementation of racial-hygienic and eugenic paradigms led to a wider definition of 'hereditary epilepsy' and an increase in sterilizations of patients suffering from epilepsy. Neurological research institutions, such as the Kaiser Wilhelm Institute in Berlin-Buch, became involved in the 'euthanasia' program between 1939 and 1945, insofar as they dissected the brains of murdered patients under the guise of 'accompanying research' and, in this way, produced neurological findings. Key Messages:
\end{abstract}

The Nazi state and German neurology provided each other with 'resources' at many levels. After 1945, the professional community showed very little interest in this legacy of neurology in the NS. It was only several generations later that the subject could be approached in an unbiased manner, allowing for comprehensive research projects.

(c) 2016 S. Karger AG, Basel

\section{Introduction}

There have been many publications in the last 30 years that dealt with the crimes of German doctors during $\mathrm{Na}$ tional Socialism (NS) [1]. Many medical associations too have vigorously discussed their own role and that of their members between 1933 and 1945 [2]. It was against this background that the authors were commissioned by the German Neurological Society to prepare a summary view of this discipline's role and open up for practicing neurologists the scattered findings of previous research [36]. The intention behind this paper is to document the research done thus far and to make it accessible for an international readership.

The article focuses on schools of thought and events during the 12 years of what came to be known as the 'Third Reich'. An examination of these developments,

\section{KARGER}

E-Mail karger@karger.com

www.karger.com/ene (c) 2016 S. Karger AG, Basel

0014-3022/16/0766-0234\$39.50/0
Prof. Dr. med. Axel Karenberg

Institute for the History of Medicine and Medical Ethics

University of Cologne, Medical Faculty

Joseph-Stelzmann-Strasse 20, DE-50931 Cologne (Germany)

E-Mail ajg02@uni-koeln.de 
however, requires a deeper understanding of the historical continuum of ideas and actions from the late 19th to the early 21st century. Therefore, this overview begins with a look at the beginnings of neurology in Germany and then extends up until the present day.

\section{Institutionalization of German Neurology}

The development of clinical neurology as a separate subject in Germany was marked by a nearly 100 -year dispute between internists, psychiatrists and neurologists [7]. This is why separate professorships for neurology an essential characteristic of an established discipline were set up only in a few places such as Hamburg and Heidelberg. Despite all this, the 'Deutsche Zeitschrift für Nervenheilkunde' (German Journal of Neurology) was launched in 1890, and it advocated for the discipline's autonomy. A specialized association, 'Gesellschaft Deutscher Nervenärzte' (Society of German Neurologists, or GDN), was founded in 1907. Nevertheless, German neurology was still a 'hampered discipline' at the start of the 20th century by international standards. This did not concern professional standing at all, but merely referred to the delay in institutionalizing the discipline [8].

The new political power constellations in and after 1933 put a complete stop to neurologists' aspirations towards autonomy. On the order of the Reich government, GDN was merged with the German Society of Neurologists and Psychiatrists (GDNP) on September 2, 1935 [9]. The first 'Reich leader' was a psychiatrist called Ernst Rüdin (1874-1952), a staunch National Socialist, racial hygienist and eugenicist [10]. In his opening speech on the occasion of the association's meeting Rüdin claimed that this move had been in the interest of those concerned, 'it was the desire of many psychiatrists and neurologists, as well as of the national government, to counter the divergent trends of the specialization through consolidating efforts. As a result, we have reunited neurologists and psychiatrists in one single association again' (quoted in [7]; this and the following translations by the authors if not stated otherwise).

Rüdin also left no doubts about the ideological orientation:

Psychiatric and neurological conditions that are more serious in nature are, to the greatest extent, hereditary and can therefore be contained and eradicated only through eugenics (...) In view of the many serious, hereditary diseases and many other conditions where heredity is at least a substantial contributor, our collabora-

German Neurology and the 'Third Reich'

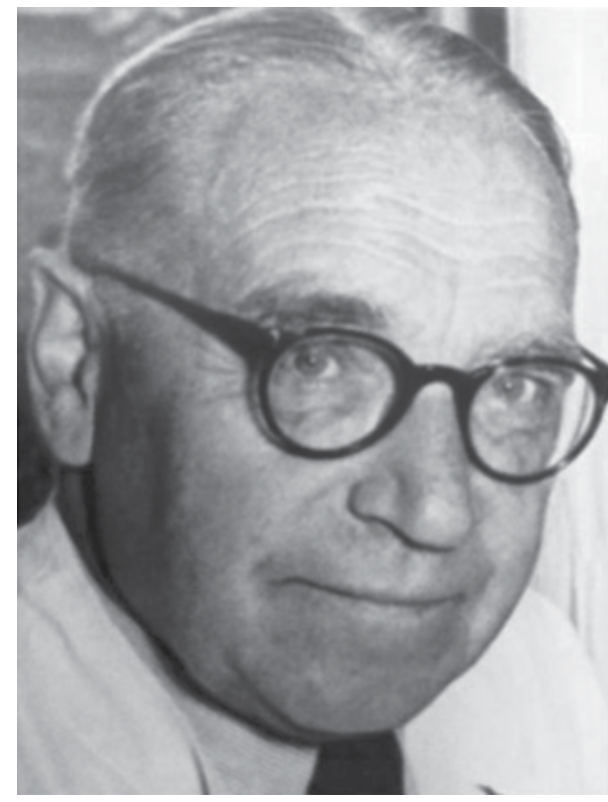

Fig. 1. Heinrich Pette (1887-1964). http://www.neuropenews.org/ wp-content/uploads/2015/01/Heinrich-Pette.jpg.

tion is more than justified (...) The new German State, thus, needs psychiatrists and neurologists trained and active in eugenics, and vice versa: neurologists and psychiatrists dedicated to racial hygienics need the National Socialist movement and the new State (quoted in [7]).

Rüdin outlined a relationship of mutual dependence between science and politics, which in the research literature is described as 'resources for one another' [11]. The Neurology Department of the new association was chaired by Heinrich Pette (1887-1964), director of the Neurological University Hospital in Hamburg (fig. 1). Pette had been a member of the National Socialist German Workers' Party since 1933 and also joined further National Socialist organizations, such as the NS Medical Association. In July 1934, he was appointed regular associate professor of neurology in Hamburg to replace Nonne.

In the following years, Rüdin would regularly open the annual meetings of GDNP and renew his commitment to hereditary and/or eugenicist ideology. He would be followed by Pette, who did not so much as mention the previous speaker [9]. Despite Pette's restraint, the speeches and discussions of the first 2 annual meetings alone exhibited a strong focus on National Socialist eugenics. Numerous contributions dealt with the 'genetic biology' of neurological and psychiatric conditions [12]. 


\section{Expulsion and Killing of 'Non-Aryan' Neurologists and Neuroscientists}

The change in government in 1933 was matched by a radical rupture in the academic and scientific community. Personnel and appointment policy became a central tool of control, which focused on the expulsion of actual and alleged opponents, on personnel renewal through a forced generational change, as well as on the 'political selection' of scientists who would work in the Nazi State. On the one hand, the process was characterized by repression, cleansing and persecution, and on the other hand, by promotion and integration. What followed was a consolidation of regulated and voluntary coordination [13].

Many doctors were classified as Jewish according to the National Socialistic laws or were for historical reasons of Jewish religion. Starting in mid-1933, efforts began to remove them from public service in substantial numbers. The measures were focussed particularly on medical schools. Among clinical subjects, neurology and psychiatry had the highest percentage of dismissed professors and teachers (65\%) [14]. Some of the dismissed neurologists and neuroscientists were driven to suicide by the regime (Felix Plaut, probably Fritz Chotzen) or killed in concentration camps (Ludwig Pick, Hans Pollnow, Arthur Simons, Otto Sittig). At this point, at least 68 doctors and scientists - among them many reputable personalities - are known to have been forced into emigration, to have been deported or to have committed suicide [15-17] (table 1). What is more, this turning point of 1933 has served, over the long term and even up to today, as a way to negate the victims' life achievements. By way of a damnatio memoriae [18], they have been excluded from biographies and left out of the history of the subject and of universities, their existence having been erased beyond their deaths (fig. 2). There are still major gaps, particularly in the field of emigration research, that need to be filled in as soon as possible.

The science policy of the Nazi regime simultaneously opened up an immense pool of jobs for previously unemployed young physicians [10]. These positions were filled by 'Aryan' doctors who found new career opportunities such as in eugenics. It was in this field that the National Socialist government provided substantial material and symbolic resources. This was a particular boon to psychiatrists and neurologists who started working at the newly established 'hereditary-health courts'.

Overall, the German medical profession was marked by a high degree of National Socialist regulation. At the same time, though, half the physicians were not members of any of the organizations mentioned. This may serve as clear evidence of the leeway that some enjoyed at the time, because these non-aligned doctors did not automatically face sanctions. Contrary to what was commonly believed in the post-war era, there was no obligation to join the party. One could definitely advance professionally at public institutions, such as universities, without becoming a member [10]. Examples are the inventor of electroencephalography Hans Berger (1873-1941) and Hans Gerhard Creutzfeldt (1885-1964), well known for his description of the Creutzfeld-Jakob disease, who had been the director of the clinic for neurology and psychiatry in Kiel. This was also true of neurologists, who complied, largely without resistance, with Rüdin's objectives of 'psychiatric genetics'. Such an approach, therefore, cannot be called anything but a form of 'voluntary coordination'.

\section{Epilepsy Research}

Eugenics became a political state objective in conjunction with the change of power. The new state, according to a programmatic essay in 1933 , had to 'prevent the unrestrained reproduction of genetically inferior life'. It went on to say that the objective of regular racial care was to 'promote the reproduction of the superior and to eliminate the inferior' (quoted in [19]; fig. 3).

The corresponding 'law for the prevention of hereditarily diseased offspring' (GzVeN) entered into force on January 1, 1934. This probably represented the most momentous legal provision for medicine in general, and for neurology and psychiatry in particular. The law listed diseases and syndromes as 'potentially requiring sterilization', and it was 'hereditary epilepsy' that triggered the most intense discussions among neurologists and, above all, between neurologists and psychiatrists [20]. The focus was on the question of heredity. Accordingly, research saw a massive intensification of efforts in the field of genetics, such as at Rüdin's German Research Institute for Psychiatry in Munich and at the Rhenish-Provincial Institute for Psychiatric-Neurological Genetic Research in Bonn, which was headed up by Kurt Pohlisch (18931955) and Friedrich Albert Panse (1899-1973).

Apart from institutionalized research, an extensive education campaign was mounted across the German Reich by way of lectures, courses or special series of essays in trade journals. In March 1934, the psychiatric department of the Berlin Charité hospital offered a genetics 
Table 1. Expelled and murdered neurologists and neuroscientists (based on [15-17])

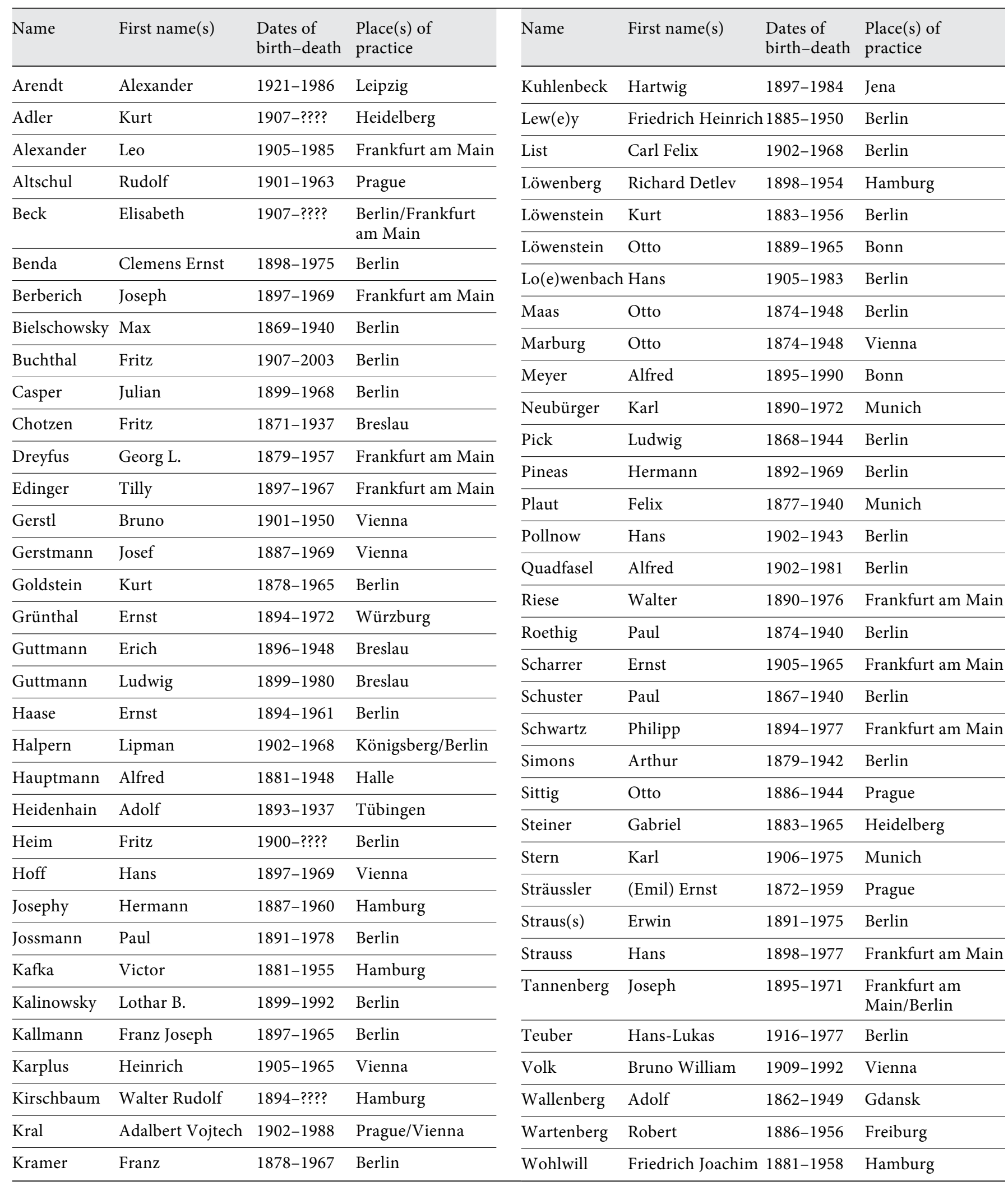


Fig. 2. Lipman Halpern, fled 1934 from Germany, one of the founders of clinical neurology in Israel; ward round (ca. 1955; private collection).

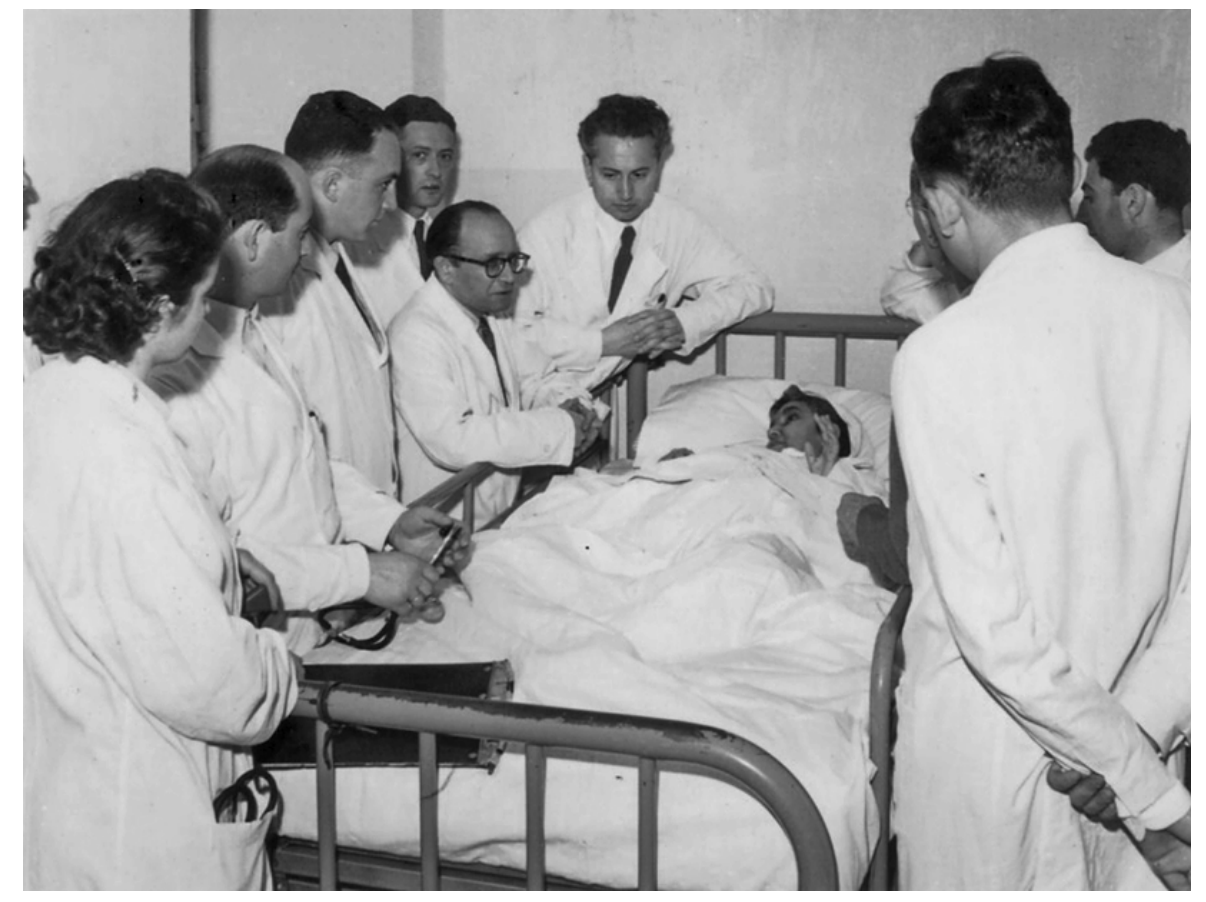

course for neurologists and psychiatrists, which was to enlighten participants about the various diseases covered under the GzVeN law, as well as about sterilization techniques [21]. The presentations given during this course were published the same year. In his foreword, the professor for psychiatry and neurology in Berlin, Karl Bonhoeffer (1868-1948), stressed that the GzVeN law and medicine interacted with each other. He saw the law as a 'strong stimulus' for further research, for example, on the heredity of epilepsy. Although Bonhoeffer contradicted the majority of his colleagues when he distinguished between hereditary and non-hereditary forms of 'genuine' epilepsy, he never questioned the heredity of epilepsy in principle, nor did he criticize forced sterilizations [21]. This topic was also discussed repeatedly at the level of the professional society. In fact, epilepsy was the main topic at the third annual meeting of the GDNP in 1937. As a kind of response to diagnostic uncertainty, it was to discuss, in particular, 'the latest in epilepsy research'. Thirteen lectures were presented on the subject of epilepsy at the joint meeting of the neurology and psychiatry departments. In his speech, Pohlisch remarked on the growing interest as follows:

The issue of epilepsy is being discussed now more than ever. It emerges, time and again, as a subject of conferences, monographs and other scientific treatises. What stimulates the discussion in Germany the most is the law for the prevention of hereditarily dis- eased offspring. Gaining a thorough understanding of hereditary epilepsy, which is part of the subject, is at this point the most important task in the extensive and still largely unexplained field of epilepsy [22].

Given this perspective, it was the GzVeN law that was the driving force behind epilepsy research, which was to legitimize the law in scientific terms.

\section{Brain Research}

In the first half of the 20th century, Germany's brain research institutes were among the world's leading institutions in the field, particularly the Kaiser Wilhelm Institute (KWI) for Brain Research in Berlin-Buch. Built by the researchers Oskar and Cécile Vogt, husband and wife, in the 1920s, the KWI opened in February 1930 and was considered the largest and most modern brain research institute in the world (fig. 4).

After the dismissal of Oskar Vogt for political reasons in 1937, the KWI too was faced with a reorientation. Under the new director Hugo Spatz (1888-1969), neuropathology and eugenics became vitally important [23]. This turning point was marked by the Institute's entering into close cooperation with the psychiatric hospitals in Greater Berlin. Furthermore, Spatz hired Julius Hallervorden (1882-1965) as director of the central morgue of the psy- 


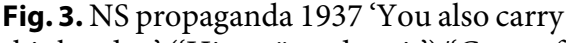
this burden' ('Hier trägst du mit')/'Costs of hereditary unfit' ('Kosten Erbkranker'). Published in: Volk und Rasse, Illustrierte Monatszeitschrift für deutsches Volkstum 1936; 10:335. (http://www.dhmd.de/file admin/user_upload/uploads_drei/ pressefotos/DEME_PRESSEFOTOS/PF_ Lehrbuch_Hier_traegst_komprimiert. jpg).

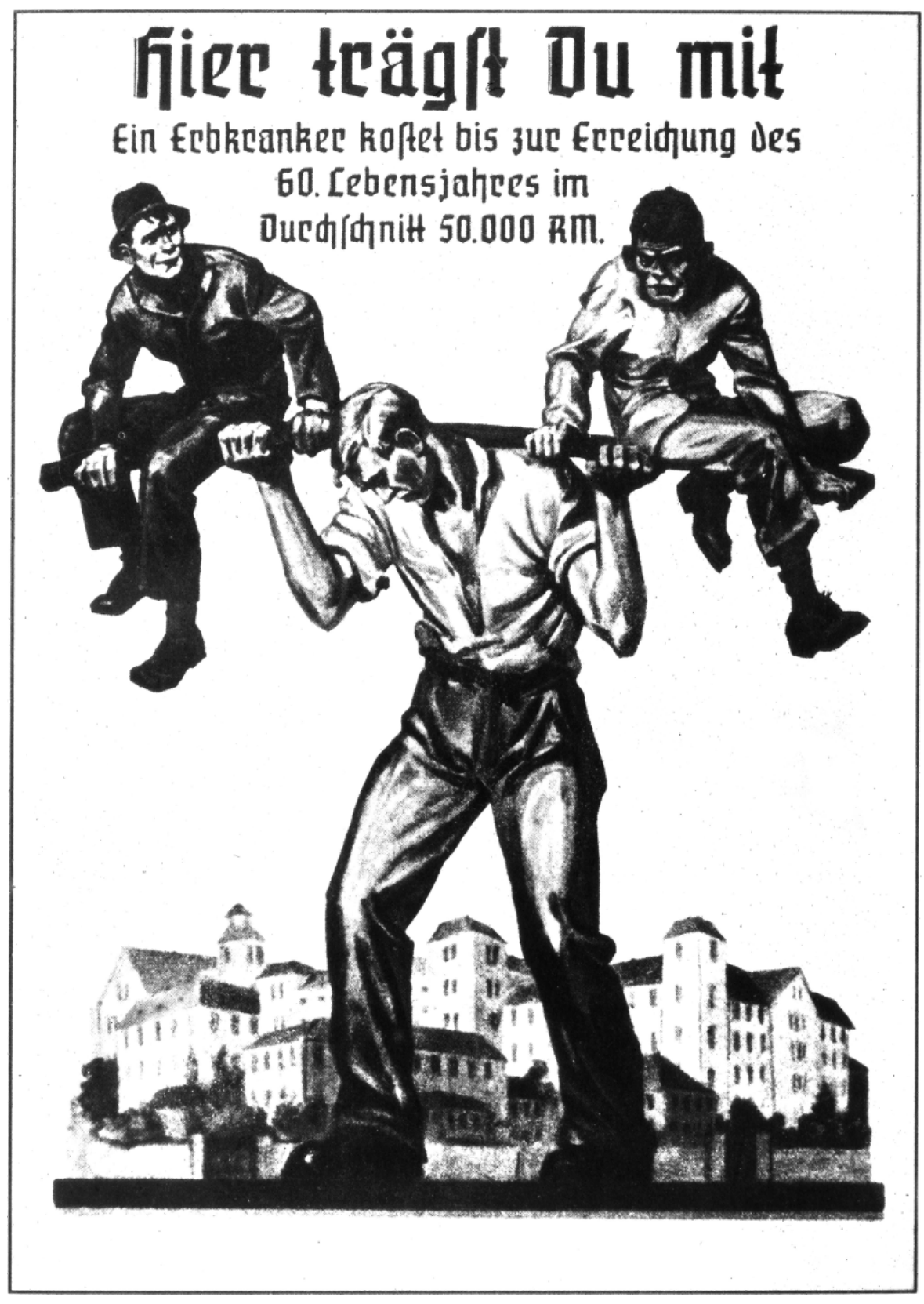

chiatric hospitals in Berlin-Brandenburg and of the KWI's histopathology department [24]. This development at the KWI represented an opening, in terms of research policy, toward psychiatry as well as an integration of brain research and institutionalized psychiatry, which was pursued vigorously from that moment on [25].

Starting in 1939/1940, the KWI was integrated into the 'accompanying research' in connection with 'euthanasia', receiving brains from 'euthanasia' victims as a result. As early as May 15, 1940, Hallervorden's department - as part of the 'euthanasia' of children - took receipt of the first brains of children killed at the Brandenburg penitentiary. A personal statement made by him confirms that Hallervorden himself was present on October 28, 1940, for the killing of a group of children and removed their brains. He wrote to Paul Nitsche (1876-1948) - head assessor and medical director of the forced euthanasia program 'Action T4' - about this on March 9, 1944: 'In total, I have received 697 brains, including those I removed in Brandenburg myself (quoted in [26]). 
Fig. 4. Building of the KWI for Brain Research in Berlin-Buch (1931; from [26], with permission of Springer-Verlag).

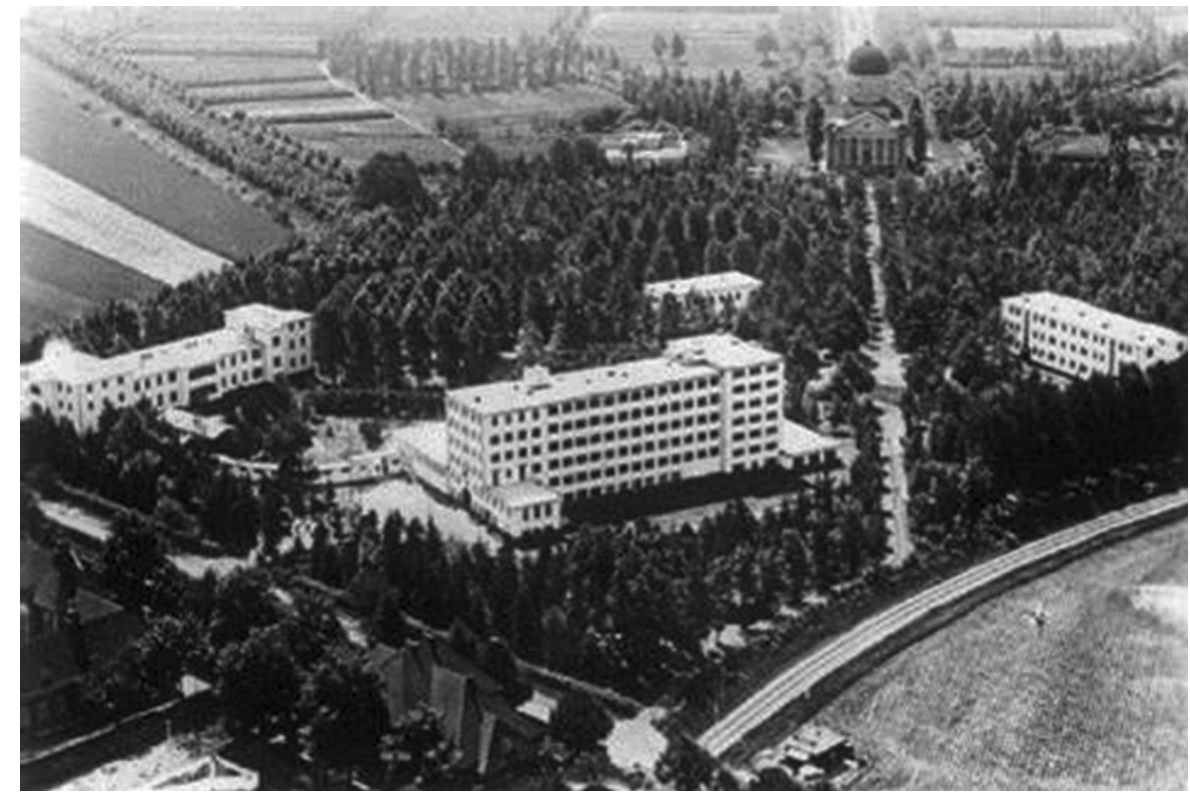

There is little doubt that his superior Spatz had been informed in detail. What is certain is that around 700 brains from 'euthanasia' victims were examined at the KWI between 1940 and 1945 [27]. The selection and delivery of victims' brains to the KWI was not centrally controlled; it was rather through personal networks into which the institute and its staff had been integrated [25]. A number of 'killing doctors' had shadowed Hallervorden and, therefore, knew about his areas of scientific work. Those to be killed were selected on the basis of the diagnostic spectrum that was of interest to the senior physicians - in the case of Hallervorden, for example, 'idiocy', cerebral palsy, epilepsy and infantile cerebral atrophy [27]. Medical research interest was elevated to the status of selection criterion for 'research children' [28], as they were called in Nazi terminology. This refers to the children who were killed and whose brains were removed to use them for neuroscientific research. Especially well documented are the operations at the 'research department' of the Psychiatric University Hospital in Heidelberg [29, 30].

Hallervorden himself repeatedly stressed the importance of his scientific interest in 'accompanying research'. In a conversation with Leo Alexander (1905-1985), who was forced to leave Germany in 1933 for being a 'Jew' and who conducted numerous interviews with German neurologists, psychiatrists and neuropathologists for the American military government after the end of the war, Hallervorden had emphasized the fact that he himself had taken the initiative to cooperate with the 'euthanasia' apparatus [25]. In his diary, Alexander documented a corresponding statement by Hallervorden verbatim and in German:

I've heard that this was going to be done, so I approached them and told them, well, if you kill them all, then at least take out their brains so that the material can be used. They asked me then, well, how many can you examine, and I said, an unlimited number - the more, the better (...) I took them, the brains, where they came from, that wasn't my business. There were beautiful deformations of idiocy and infantile diseases (quoted in [31]).

The motives behind the killings were, despite claims of alleged 'scientific interest', economic in nature, sometimes associated with eugenic motives ('health of the body of the German people'). In view of this 'untrammeled' research landscape, it is astonishing that only few publications should have emerged from the examinations of 'euthanasia' victims. Peiffer identified a total of 25 for the Hallervorden department at the KWI in Berlin, the vast majority of which (18) were not published until the period between the end of the war and 1959 [32].

\section{Impact and Consequences after 1945}

The Nuremberg Doctors' Trial took place from December 9, 1946, to August 20,1947. At the core of the indictment charges were medical experiments that had 
Fig. 5. Collection of specimen at the KWI in Berlin-Buch (from [26], with permission of Springer-Verlag).

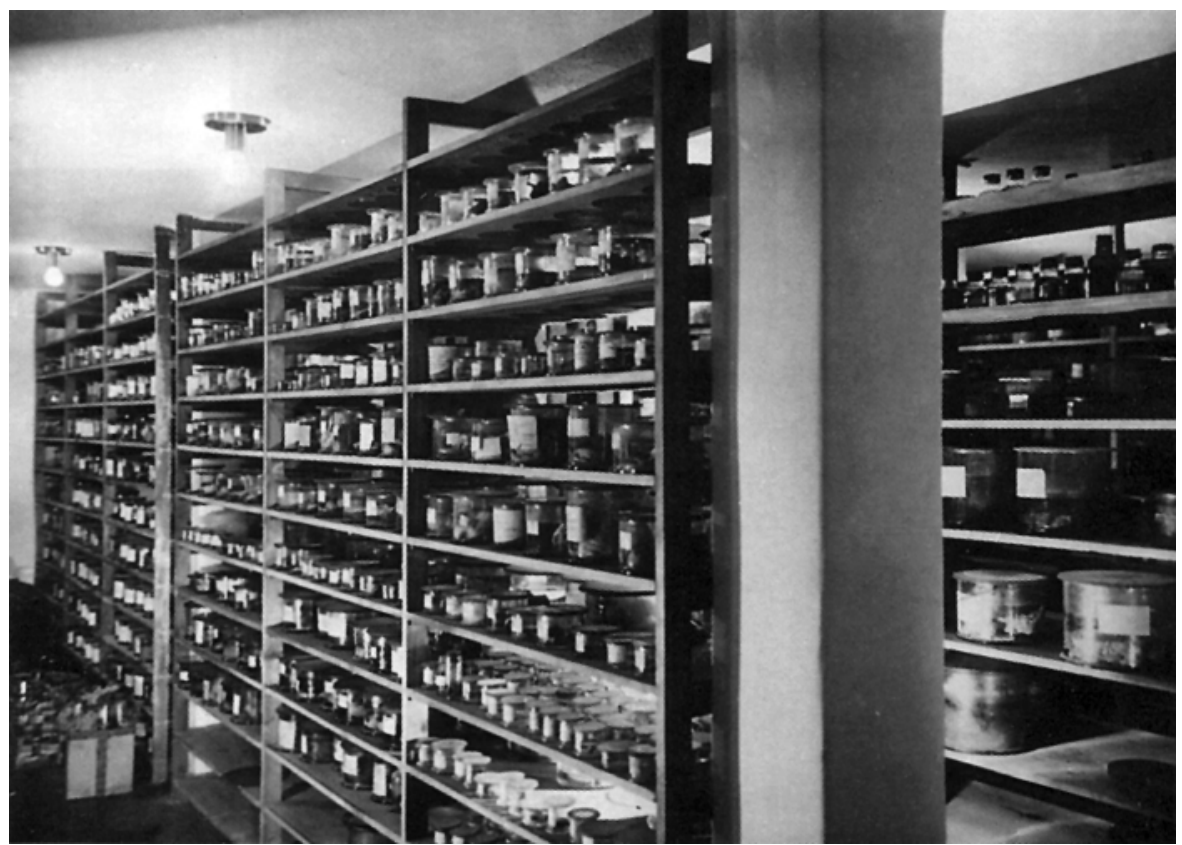

been performed on concentration camp inmates. Compared to this, forced sterilization and 'euthanasia' were pushed in to the background [33]. No neurologists were indicted. Thus, a point of view prevailed in the post-war years that favored separating individual perpetrators. Medical research as part of 'everyday' operations at universities and institutes was not of interest to the prosecution, nor was it debated publicly.

On an international level, representatives of German neurology also intended to put an end to discussion about the Nazi past. Hallervorden participated in international conferences during 1950 in Paris and 1952 in Rome. However, when he was invited to the 5th International Congress of Neurology in Lisbon, especially Dutch neurologists protested. They threatened to boycott the congress if Hallervorden participated. Nevertheless, his German colleagues supported Hallervorden. The GDNP and the newly founded German Society of Neurology (Deutsche Gesellschaft für Neurologie, DGN) published a joint statement that 'all accusations against Herrn Hallervorden are wrong' and that the societies 'backed without restrictions their renowned member'.

It was not until the late 1960s that the attitude of 'hushing up' the National Socialist past began to be criticized, and from the 1990s on, one has seen a gradually increasing degree of differentiation and professionalization in the research done by (medical) historians. An important issue in this was the way in which medical research findings would be handled that had been obtained from unethical human experiments and/or specimens derived from murder. For example, the extensive collection of brain sections, which had been assembled at the KWI in Berlin-Buch under Hallervorden, was moved around several times before it ended up in Frankfurt (fig. 5). Hallervorden, Spatz and others and/or their students and assistants continued to work on the specimens, with the latter generally being ignorant of their origin. When historian Götz Aly made this public in the 1980s, it caused quite a stir [34], but Aly was not alone. On an international level, for example, the anatomist William E. Seidelman declared himself in favor of a dignified handling of the specimen [36]. In 1990, the brain sections were officially buried at the Waldfriedhof cemetery in Munich, and the Max Planck Society erected a memorial to the victims there. However, as Weindling [35] stated, this way of dealing with the affair to a great deal prevented the reconstruction of the victims' identities. A similar situation occurred with the brain specimens from children killed at the 'Am Spiegelgrund' orphanage and children's ward in Vienna. In this case too, the origins had long been obscured until the remains were buried at Vienna's Central Cemetery in 2002 ([37]; on anatomy c.f. [42]).

Comparing today's situation with that of 1990, one can determine a number of striking developments. Starting with isolated critical voices, the topic of 'Nazi 
neurology' today takes up a much more prominent place in the internal debate among neurologists in Germany. The now-published research overview will, hopefully, carry the debate further and trigger new research. This should extend also to a critical and historically informed approach to eponyms, such as Hallervorden-Spatz disease. Beginning with Shevell's paper on Hallervorden's past [24] from 1992 on the controversial eponym was used less and little [38, 39]. Nevertheless, it was suggested that the so-called 'tainted eponyms' [40] should be accompanied by an addition like 'NBIA (Neurodegeneration with Brain Iron Accumulation; obsolet: Hallervorden-Spatz-Syndrom)' in order not to forget the historical background of physicians' crimes under the NS regime. Similarly, Hugo Spatz's role during the 'Third Reich' was discussed in the German Society of Neurology in the year 1998 when the designated award winner of the 'Hugo-Spatz-Prize' (awarded by the Society since 1975) Tobias Back critically asked for Spatz's participation in unethical research. After the discussion, the prize was renamed the 'Adolf-Wallenberg Prize' [41]. At the same time, a transition from external to self-labeling with respect to historical responsibility has become noticeable among German neurologists. The multiple generational change since 1945 has undoubtedly contributed to this change of perspective in a substantial manner. From the generation of contemporary witnesses, to students and grandchildren, today's generation is no longer afraid of addressing the Nazi past of their discipline, nor of any loss of prestige that may ensue.

\section{Conclusions}

The common phrase that 'this must never happen again' as the sole conclusion drawn from the history of neurology during NS is both applicable and fair. The conclusion that research in the Third Reich illustrated the potential for science, academia and physicians to be corrupted in a totalitarian society is correct, but falls short. In addition, there are other considerations to keep in mind.

The events between 1933 and 1945 changed the image of German medicine drastically. It has become clearer than ever before that there is no hermetically isolated science that seeks pure truth from within its ivory tower. Scientists and physicians do have a moral responsibility for consequences and undesirable developments. Moreover, the crimes committed in the name of medicine dur-

ing the Third Reich have shown the degree to which medical research and practice depend on societal expectations, political pressure and financial conditions. This is no different today than it was then, even though the circumstances and general conditions are fundamentally different.

'Nazi neurology', in particular, leaves no doubt that medical research on people can come into conflict with ethical values related to therapeutic relationships, human dignity and general respect between people [43]. Ever since medicine became linked to natural sciences, there has been a potential for destruction in this association. Wherever acquisition of knowledge is considered the main objective that is superior to all other moral values, science will reveal its 'dark side', not only during the Third Reich and in other totalitarian regimes but in democratic states as well if moral resistance is too weak. Progress without humaneness is possible in any type of research.

Historiography is not the same as personal memories. History is constructed memory based on facts and data; memories are subjective and emotional. International science requires both types of cultural memory in order to learn about itself. This also applies to German neurology and the processing of its Nazi past.

\section{Disclosure Statement}

This research was in part funded by the DGN (German Neurological Society). It was part of the contract with the sponsor that the DGN had no influence on research and publication.

References

Eur Neurol 2016;76:234-243 DOI: $10.1159 / 000450851$
1 Jütte R, Eckart WU, Schmuhl HW, Süß W (eds): Medizin und Nationalsozialismus: Bilanz und Perspektiven der Forschung. Göttingen, Wallstein, 2011.

2 Schmuhl HW: Die Gesellschaft Deutscher Neurologen und Psychiater im Nationalsozialismus. Berlin and Heidelberg, Springer, 2016.

3 Martin M, Karenberg A, Fangerau H: Neurologie und Neurologen in der NS-Zeit: Voraussetzungen und Rahmenbedingungen vor und nach 1933. Nervenarzt 2016;87(suppl 1):5-17.

4 Martin M, Fangerau H, Karenberg A: Neurologie und Neurologen in der NS-Zeit: Das Beispiel der Epilepsieforschung. Nervenarzt 2016;87(suppl 1):18-29.

5 Martin M, Karenberg A, Fangerau H: Neurologie und Neurologen in der NS-Zeit: Hirnforschung und 'Euthanasie'. Nervenarzt 2016; 87:30-41. 
6 Martin M, Fangerau H, Karenberg A: Neurologie und Neurologen in der NS-Zeit: Auswirkungen und Folgen von 1945 bis heute. Nervenarzt 2016;87:42-52.

7 Pantel J: Streitfall Nervenheilkunde - eine Studie zur disziplinären Genese der klinischen Neurologie in Deutschland. Fortschr Neurol Psychiatr 1993;61:144-155.

8 Karenberg A: Die Gründung der 'Gesellschaft Deutscher Nervenärzte' und die schwierigen Anfänge der klinischen Neurologie in Deutschland. Schriftenreihe der Deutschen Gesellschaft für Geschichte der Nervenheilkunde 2008;14:319-345.

9 Firnhaber W: Die Gesellschaft Deutscher Nervenärzte (GDN) während der Zwangsvereinigung zur Gesellschaft deutscher Neurologen und Psychiater (GDNP) in den Jahren 1934 bis 1939. Schriftenreihe der Deutschen Gesellschaft für die Geschichte der Nervenheilkunde 2009;15:387-402.

10 Roelcke V: Ernst Rüdin - renommierter Wissenschaftler, radikaler Rassenhygieniker. Nervenarzt 2012;83:303-310.

11 Ash MG: Wissenschaft und Politik als Ressource füreinander; in vom Bruch R, Kaderas $B$ (eds): Wissenschaften und Wissenschaftspolitik: Bestandsaufnahmen zu Formationen, Brüche und Kontinuitäten in Deutschland des 20. Jahrhunderts. Stuttgart, Steiner, 2002, pp 32-51.

12 Schmuhl HW: Psychiatrie und Politik: Die Gesellschaft Deutscher Neurologen und Psychiater im Nationalsozialismus; in Lohff B, Wolters C, Beyer C (eds): Abweichung und Normalität: Psychiatrie in Deutschland vom Kaiserreich bis zur Deutschen Einheit. Bielefeld, transscript Verlag, 2012, pp 137-158.

13 Ferdinand U: Vertreibungen im Umgestaltungsprozess der Medizinischen Fakultäten an den deutschen Universitäten im 'Dritten Reich'; in Beddies T, Doetz S, Kopke C (eds): Jüdische Ärztinnen und Ärzte im Nationalsozialismus: Entrechtung, Vertreibung, Ermordung. Berlin, de Gruyter, 2014, pp 117149.

14 Kröner HP:Die emigration deutschsprachiger mediziner im nationalsozialismus. Ber Wiss 1989;12:1-44.

15 Peiffer J: Die Vertreibung deutscher Neuropathologen 1933-1939. Nervenarzt 1998;69: 99-109.

16 Krämer G: Personal Communication, 2014.

17 Holdorff B: Emigrated neuroscientists from Berlin to North America. J Hist Neurosci 2016;25:227-252.

18 Voswinckel P: Damnatio memoriae: Kanonisierung, Willkür und Fälschung in der ärztlichen Biographik; in Bayer $\mathrm{K}$, Sparing $\mathrm{F}$, Woelk W (eds): Universitäten und Hoch- schulen im Nationalsozialismus und in der frühen Nachkriegszeit. Stuttgart, Steiner, pp 249-270.

19 Bialas W: Moralische Ordnungen des Nationalsozialismus. Göttingen, Vandenhoek \& Ruprecht, 2014

20 van den Bussche H: Die versuchte Deprofessionalisierung der Neurologie im Nationalsozialismus - ein Beitrag zur laufenden Diskussion. Schriftenreihe der Deutschen Gesellschaft für die Geschichte der Nervenheilkunde 2015;21:89-125.

21 Möller T: Vom wissenschaftlichen Wissen zum gesellschaftlichen Vorurteil: Erblichkeit und Psychopathologie im deutschen Epilepsiediskurs. Frankfurt am Main, Mabuse-Verlag, 2010.

22 Firnhaber W: Inwieweit beeinflussten nationalsozialistische rassenhygienische und erbbiologische Ideen die Jahresversammlungen der Gesellschaft Deutscher Neurologen und Psychiater (GDNP) 1936 in Frankfurt und 1937 in München? Schriftenreihe der Deutschen Gesellschaft für die Geschichte der Nervenheilkunde 2012;18:419-429.

23 Weber MM: Geschichte der Kaiser-WilhelmGesellschaft im Nationalsozialismus: Aus den Zwischenberichten der Präsidentenkommission der Max-Planck-Gesellschaft. Nervenarzt 2002;73:1107-1111.

24 Shevell MI: Racial hygiene, active euthanasia, and Julius Hallervorden. Neurology 1992;42: 2214-2219.

25 Schmuhl HW: Hirnforschung und Krankenmord: Das Kaiser-Wilhelm-Institut für Hirnforschung 1937-1945. Berlin, 2000 (Forschungsprogramm Geschichte der Kaiser-Wilhelm-Gesellschaft im Nationalsozialismus 1).

26 Bielka H: Kaiser-Wilhelm-Institut für Hirnforschung 1930-1945; in Bielka H (ed): Die Medizinisch-Biologischen Institute BerlinBuch. Berlin and Heidelberg, Springer, 1997, pp 18-39.

27 Peiffer, Jürgen: Neuropathologische Forschung an 'Euthanasie'-Opfern in zwei KaiserWilhelm-Instituten; in Kaufmann D (ed): Geschichte der Kaiser-Wilhelm-Gesellschaft im Nationalsozialismus: Bestandsaufnahme und Perspektiven der Forschung. Göttingen, Wallstein, 2000, pp 151-173.

28 Reicherdt B: 'Gördener Forschungskinder' NS-'Euthanasie' und Hirnforschung; in Rotzoll M, Hohendorf G, Fuchs P, Mundt C, Eckart WU (eds): Die nationalsozialistische ' $\mathrm{Eu}$ thanasie'-Aktion 'T4' und ihre Opfer: Geschichte und ethische Konsequenzen für die Gegenwart, Paderborn, Schöningh, 2010, pp 147-151.

29 Rotzoll M, Roelcke V, Hohendorf G: Tödliche Forschung an Kindern: Carl Schneiders
'Forschungsabteilung' an der Heidelberger Psychiatrischen Universitätsklinik 1943/44; in Beddies $\mathrm{T}$ (ed): Im Gedenken der Kinder: Die Kinderärzte und die Verbrechen an Kindern in der NS-Zeit. Berlin, Eigenverlag, 2011, pp 35-42.

30 Rotzoll M, Hohendorf G: Die Psychiatrischneurologische Klinik; in Eckart WU, Sellin V, Wolgast E (eds): Die Universität Heidelberg im Nationalsozialismus. Berlin and Heidelberg, Springer, 2006, pp 909-939.

31 Peiffer J: Hirnforschung im Zwielicht: Beispiele verführbarer Wissenschaft aus der Zeit des Nationalsozialismus. Julius Hallervorden - H. J. Scherer - Berthold Ostertag. Husum, Matthiesen, 1997.

32 Peiffer J: Assessing neuropathological research carried out on victims of the 'euthanasia’ programme. Medizinhist J 1999;34:339355

33 Ebbinghaus A, Dörner K (eds): Vernichten und Heilen: Der Nürnberger Ärzteprozess und seine Folgen. Berlin, Aufbau Taschenbuch Verlag, 2001.

34 Aly G: Die Belasteten: 'Euthanasie' 19391945, eine Gesellschaftsgeschichte. Frankfurt am Main, Fischer, 2013

35 Weindling P: 'Cleansing' anatomical collections: the politics of removing specimens from German anatomical and medical collections 1988-1992. Ann Anat 2012;194:237242

36 Seidelman WE: Dissecting the history of anatomy in the Third Reich - 1989-2010: a personal account. Ann Anat 2012;194:228-236.

37 Czech H: Forschen ohne Skrupel: Die wissenschaftliche Verwertung von Opfern der NSPsychiatriemorde in Wien; in Gabriel E, Neugebauer W (eds): Von der Zwangssterilisierung zur Ermordung: Zur Geschichte der NS-Euthanasie in Wien Teil II. Böhlau, Wien, 2002, pp 143-163.

38 Shevell M: The declining use of the Hallervorden-Spatz eponym. J Child Neurol 2012;27: 1308-1309.

39 Zeidman LA, Pandey DK: Declining use of the Hallervorden-Spatz disease eponym in the last two decades. J Child Neurol 2012;27: 1310-1315.

40 Vajda FJ, Davis SM, Byrne E: Names of infamy: tainted eponyms. J Clin Neurosci 2015; 22:642-644.

41 Back T: Personal Communication, 2016.

42 Hildebrandt S: The Anatomy of Murder: Ethical Transgressions and Anatomical Science during the Third Reich, New York and Oxford, Berghahn, 2016.

43 Zeidman LA: The central role of neuroscientists under National Socialism. Front Neurol Neurosci 2016;38:168-183. 